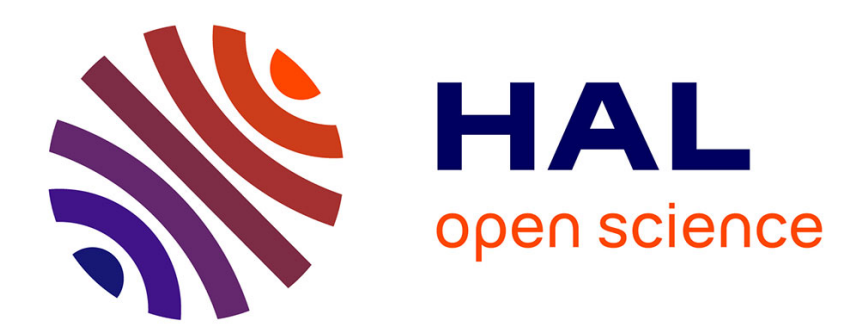

\title{
True Performance Metrics in Electrochemical Energy Storage
}

\author{
Y. Gogotsi, Patrice Simon
}

\section{To cite this version:}

Y. Gogotsi, Patrice Simon. True Performance Metrics in Electrochemical Energy Storage. Science Magazine, 2011, vol. 334, pp.917-918. hal-00714212

\section{HAL Id: hal-00714212 \\ https://hal.science/hal-00714212}

Submitted on 3 Jul 2012

HAL is a multi-disciplinary open access archive for the deposit and dissemination of scientific research documents, whether they are published or not. The documents may come from teaching and research institutions in France or abroad, or from public or private research centers.
L'archive ouverte pluridisciplinaire HAL, est destinée au dépôt et à la diffusion de documents scientifiques de niveau recherche, publiés ou non, émanant des établissements d'enseignement et de recherche français ou étrangers, des laboratoires publics ou privés. 


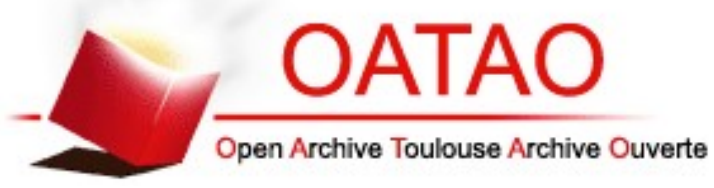

\section{Open Archive Toulouse Archive Ouverte (OATAO)}

OATAO is an open access repository that collects the work of Toulouse researchers and makes it freely available over the web where possible.

This is an author-deposited version published in: http://oatao.univ-toulouse.fr/ Eprints ID: 5873

To link to this article : DOI: 10.1126/science.1213003

URL : http://dx.doi.org/10.1126/science.1213003

\section{To cite this version:}

Gogotsi, Y. and Simon, Patrice True Performance Metrics in Electrochemical Energy Storage. (2011) Science Magazine , vol. 334 (n 6058). pp. 917-918. ISSN 0036-8075

Any correspondence concerning this service should be sent to the repository administrator: staff-oatao@listes.diff.inp-toulouse.fr 


\section{True Performance Metrics in Electrochemical Energy Storage}

\section{Y. Gogotsi' and P. Simon ${ }^{2}$}

Exceptional performance claims for electrodes used in batteries and electrochemical capacitors often fail to hold up when all device components are included.

\begin{abstract}
dramatic expansion of research in the area of electrochemical energy storage (EES) during the past decade has been driven by the demand for EES in handheld electronic devices, transportation, and storage of renewable energy for the power grid (1-3). However, the outstanding properties reported for new electrode materials may

${ }^{1}$ Department of Materials Science and Engineering and A. ]. Drexel Nanotechnology Institute, Drexel University, Philadelphia, PA 19104, USA. ${ }^{2}$ Université Paul SabatierToulouse III, CIRIMAT UMR-CNRS 5085, 118 Route de Narbonne, 31062 Toulouse, France. E-mail: gogotsi@drexel. edu,simon@chimie.ups-tlse.fr
\end{abstract}

not necessarily be applicable to performance of electrochemical capacitors (ECs). These devices, also called supercapacitors or ultracapacitors (4), store charge with ions from solution at charged porous electrodes. Unlike batteries, which store large amounts of energy but deliver it slowly, ECs can deliver energy faster (develop high power), but only for a short time. However, recent work has claimed energy densities for ECs approaching (5) or even exceeding that of batteries. We show that even when some metrics seem to support these claims, actual device performance may be rather mediocre. We will focus here 

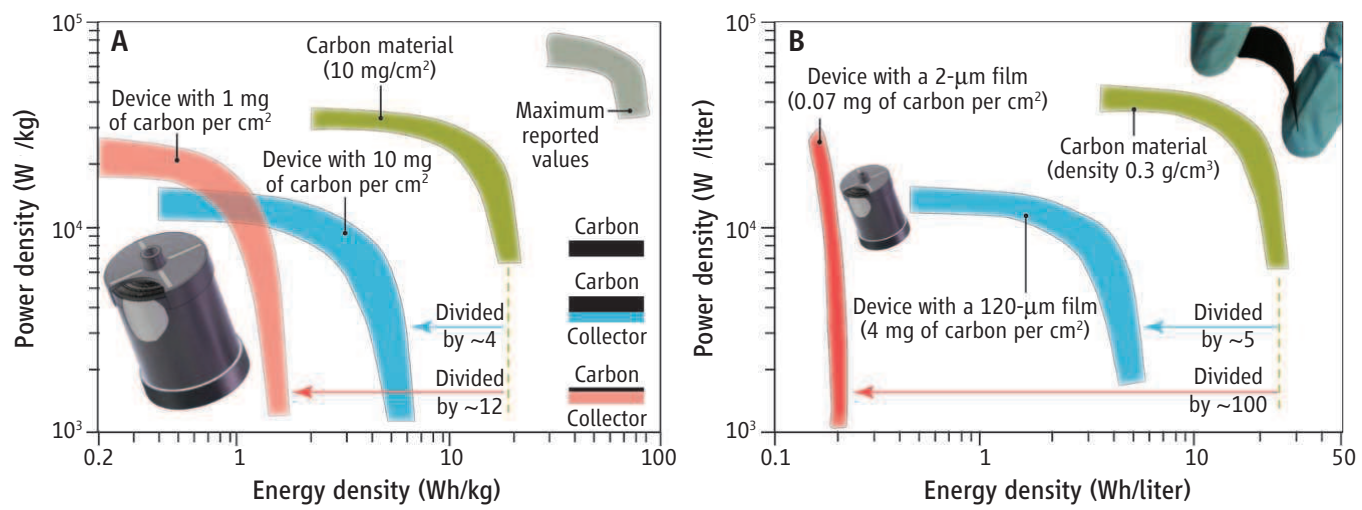

which is a typical value for commercial ECs with activated carbon. If a $2-\mu \mathrm{m}$ film of the same material is used in the device, a much greater drop occurs, which is why "paper batteries" or thinfilm ECs cannot be used for storing large amounts of energy.

The gravimetric energy density is almost irrelevant compared to areal or volumetric energy for microdevices and thin-film ECs, because the weight of the active material used in a micrometer-thin film on a chip or a nanotube coating on a smart fabric is negligible. These systems may show a very high gravimetric power density A tale of two plots. One way to compare electrical energy storage devices is to use Ragone plots (10), which show both density (speed of charge and discharge) and energy density (storage capacity). These plots for the same electrochemical capacitors are on a gravimetric (per weight) basis in (A) and on a volumetric basis in (B). The plots show that excellent properties of carbon materials will not translate to medium- and large-scale devices if thin-film and/or low-density electrodes are used (10).

on ECs, but these considerations also apply to lithium (Li)-ion batteries.

Typically, the performance of both batteries and ECs is presented by using Ragone plots (see the figure) that show the relation between energy density (how far an electric car can go on a single charge) and power density (how fast the car can go). A commercial EC can harvest or release more energy than a typical Li-ion battery can deliver on time frames of less than $10 \mathrm{~s}$, and it can be used for an almost unlimited number of charge and discharge cycles (4). A near-term application will be storing energy for car starter motors to allow engine shut-offs when stopped ( 6 ) and harvesting braking energy.

Increasing the energy density of ECs usually comes at the cost of losses in cyclability (5) or power, which are the most important properties of ECs and without which they become mediocre batteries. A major effort has been directed toward increasing the energy density of ECs by either increasing the capacitance of the material, $C$, or the operation voltage window, $V$, or both, since the energy stored is proportional to $C V^{2}$. Some recent publications on graphene and nanotube-based materials have used Ragone plots to argue that supercapacitors can achieve the energy density of batteries. Those claims are summarized in the gray area in the upper right corner of panel A in the figure.

Reporting the energy and power densities per weight of active material alone on a Ragone plot (panel A) may not give a realistic picture of the performance that the assembled device could reach because the weight of the other device components also needs to be taken into account. ECs are similar to Li-ion batteries in that they contain current collectors, electrolyte, separator, binder, connectors, and packaging, in addition to carbonbased electrodes. Because the carbon weight accounts for about $30 \%$ of the total mass of the packaged commercial EC, a factor of 3 to 4 is frequently used to extrapolate the energy or power of the device from the performance of the material. Thus, the energy density of 20 $\mathrm{Wh} / \mathrm{kg}$ of carbon will translate to about $5 \mathrm{Wh} /$ $\mathrm{kg}$ of packaged cell.

However, this extrapolation is only valid for electrodes with thicknesses and densities similar to those of commercial electrodes (100 to $200 \mu \mathrm{m}$ or about $10 \mathrm{mg} / \mathrm{cm}^{2}$ of carbon film). An electrode of the same carbon material that is 10 times thinner or lighter will reduce energy density by three- to fourfold (from 5 down to $1.5 \mathrm{Wh} / \mathrm{kg}$ based on cell weight, see panel A), with only a slight increase in power density. Our ability to predict the performance of a $200-\mu \mathrm{m}$-thick electrode by testing a $1-\mu \mathrm{m}$ film (7) or a small amount of material in a cavity microelectrode $(8)$ is still very poor. Experimental data show that there may be an additional drop in the capacitance by a factor of 2 to 3 when the thickness of the nanoporous carbon electrode increases (7).

Much of this uncertainty stems from reporting gravimetric, rather than volumetric, energy and power densities of materials and devices. Many nanomaterials, such as nanotubes or graphene, have a low packing density $\left(<0.5 \mathrm{~g} / \mathrm{cm}^{3}\right)$, which leads to empty space in the electrode that will be flooded by electrolyte, thereby increasing the weight of the device without adding capacitance. An extreme case would be the use of a carbon aerogel with $90 \%$ porosity. The volumetric energy of such an electrode will be $20 \%$ that of a carbon electrode with just $50 \%$ porosity.

If we consider a low-density graphene electrode $\left(0.3 \mathrm{~g} / \mathrm{cm}^{3}\right)$ with an extremely high gravimetric energy density of $85 \mathrm{Wh} / \mathrm{kg}$ (gray area in panel A of the figure), its volumetric density will be $25.5 \mathrm{Wh} /$ liter for the electrode and $\sim 5 \mathrm{Wh} /$ liter for the device (panel B), and discharge rates, but those characteristics will not scale up linearly with the thickness of the electrode (7), i.e., the devices cannot be scaled up to power an electric car. Ragone plots are only one measure of a device; they do not show other important properties, such as the device's cycle lifetime, energy efficiency, self-discharge, temperature range of operation, or cost. They may also provide misleading information for flow and semisolid batteries $(3,9)$, where energy and power densities are decoupled.

By presenting energy and power densities in a consistent manner, we can facilitate introduction of new materials and find solutions for EES challenges the world faces. National and international testing facilities should be created for benchmarking electrodes and devices similar to the facilities that exist for benchmarking photovoltaics. Clear rules for reporting the performance of new materials for EES devices would help scientists who are not experts in the field, as well as engineers, investors, and the general public, who rely on the data published by the scientists, to assess competing claims.

\section{References and Notes}

1. J. R. Miller, P. Simon, Science 321, 651 (2008).

2. M. Armand, ].-M. Tarascon, Nature 451, 652 (2008).

3. Z. Yang et al., Chem. Rev. 111, 3577 (2011).

4. J. R. Miller, A. F. Burke, Interface 17, 53 (2008).

5. C. Liu et al., Nano Lett. 10, 4863 (2010).

6. www.greencarcongress.com/2010/10/conti-20101014. html

7. J. Chmiola et al., Science 328, 480 (2010).

8. C. Portet et al., Electrochim. Acta 53, 7675 (2008).

9. M. Duduta et al., Adv. Energy Mater. 1, 5111 (2011).

10. Details for the figure plots are available at Science Online.

11. We thank the Partner University Fund for funding our collaborative efforts. 